\title{
PERAN TENAGA KEPENDIDIKAN DALAM PENGEMBANGAN UNIT PENDIDIKAN UNGGULAN FAKULTAS PETERNAKAN, INSTITUT PERTANIAN BOGOR
}

\author{
THE ROLE OF EDUCATIONAL PERSONNEL IN THE LEADING EDUCATION DEVELOPMENT UNIT IN \\ FACULTY OF ANIMAL SCIENCE, BOGOR AGRICULTURAL UNIVERSITY
}

\author{
Lanjarsih $^{*) 1}$, Musa Hubeis ${ }^{* *}$, dan Farid M. Afandi**) \\ *) Departemen Ilmu Nutrisi dan Teknologi Pakan, Fakultas Peternakan, Institut Pertanian Bogor \\ Jl. Agatis Kampus IPB Dramaga, Bogor 16680 \\ **) Departemen Manajemen, Fakultas Ekonomi \& Manajemen, Institut Pertanian Bogor \\ Jl. Agatis Kampus IPB Dramaga, Dramaga Bogor 16680
}

\begin{abstract}
The high levels of motivation, compensation, organizational culture, and competence of educational personnel greatly affect their performance. As the motivation, compensation, organizational culture and competence of the educational personnel of Faculty of Animal Science Bogor Agricultural University (IPB) in achieving the performance has still not been optimal, this research aimed to analyze the factors affecting the performance of the educational personnel in the Faculty of Animal Science Bogor Agricultural University (IPB), both directly and indirectly i.e. to analyze the effect of compensation on motivation, to analyze the effect of compensation on organizational culture, in which motivation serves as intervening variable, to analyze the effect of compensation on competence, in which organizational culture serves as the intervening variable, and to analyze the effect of motivation on competence. The variables include motivation, compensation, organizational culture, and competence of the academic personnel. The data collection technique was conducted by doing interviews and distributing questionnaires using the Likert scale. The reliability on the data obtained, descriptive analysis and Structural Equation Model (SEM) analysis were utilized. Based on the research results, it is revealed that the compensation variable has a significant effect on the motivation, while the compensation has no significant effects on the organizational culture in which the motivation serves as intervening variable. Thus, compensation has no significant effects on the competence in which the organizational culture serves as intervening variable, and motivation also has no significant effect on the competence.
\end{abstract}

Keywords: motivation, compensation, organization culture and competence, PLS

\begin{abstract}
Abstrak: Tinggi rendahnya motivasi, kompensasi, budaya organisasi dan kompetensi tenaga kependidikan sangat memengaruhi kinerja. Penelitian dilakukan karena motivasi, kompensasi, budaya organisasi serta kompetensi tenaga kependidikan Fakultas peternakan Institut Pertanian Bogor (IPB) dalam pencapaian kinerja masih belum optimal. Tujuan penelitian ini adalah untuk menganalisis faktor-faktor yang memengaruhi kinerja tenaga kependidikan di Fakultas Peternakan IPB baik secara langsung maupun tidak langsung, yaitu menganalisis pengaruh kompensasi terhadap motivasi, menganalisis pengaruh kompensasi terhadap budaya organisasi, dimana motivasi sebagai peubah intervening, menganalisis pengaruh kompensasi terhadap kompetensi dimana budaya organisasi sebagai peubah intervening, menganalisi pengaruh motivasi terhadap kompetensi. Peubahnya adalah motivasi, kompensasi, budaya organisasi dan kompetensi Tendik. Teknik pengumpulan data adalah dengan interview serta kuesioner menggunakan skala Likert. Peneliti menggunakan reabilitas terhadap data yang diperoleh dan selanjutnya menggunakan analisis deskriptif dan analisis Struktural Equation Model (SEM). Dari hasil penelitian diketahui peubah kompensasi berpengaruh nyata terhadap motivasi, kompensasi terhadap budaya organisasi dimana motivasi sebagai intervening tidak berpengaruh nyata, kompensasi tidak berpengaruh nyata terhadap kompetensi dimana budaya ornagisasi sebagai intervening dan motivasi tidak berpengaruh nyata terhadap kompetensi.
\end{abstract}

Kata kunci: motivasi, kompensasi, budaya organisasi dan kompetensi, PLS

\footnotetext{
${ }^{1}$ Alamat Korespondensi:

Email: moedi_anto@yahoo.co.id
} 


\section{PENDAHULUAN}

Pada era globlalisasi persaingan global semakin ketat akibat pesatnya kemajuan ilmu pengetahuan dan teknologi (IPTEK). Peran tenaga kependidikan (Tendik) merupakan pemegang peranan strategik dalam upaya pembentukan karakter bangsa dan peningkatan mutu SDM (sumber daya manusia) dalam pencapaian pendidikan unggulan baik ditingkat dasar, menengah maupun perguruan tinggi. Perkembangan IPTEK merupakan tantangan tersendiri bagi Tendik, karena dituntut mengikuti laju perkembangannya. Melalui mekanisme pengelolaan yang mencakup sistem manajerial, pembinaan dan pengembangan tenaga kependidikan dalam mendukung, pelaksanaan tri dharma Perguruan Tinggi. Pencapain pendidikan unggulan bisa diukur degan pengukuran kinerja melalui motivasi, kompensasi, budaya organisasi dan kompetesi Tendik.

Pendidikan Unggulan adalah pendidikan yang mampu membawa setiap mahasiswa mencapai kemampuan secara terukur dan mampu menunjukkan prestasinya. Fakultas unggulan dapat diartikan sebagai fakultas bermutu dan mampu memberikan harapan bagi lulusannya. Harapan tersebut berupa output yang memiliki kemampuan intelektual, moral dan keterampilan yang berguna bagi masyarakat.

Fakultas Peternakan (FAPET) IPB memiliki peranan penting di tingkat nasional dalam pengembangan akademik dalam bidang nutrisi dan makanan ternak. Untuk mempertahankan dan meningkatkan peran tersebut, khususnya menghasilkan lulusan kompetitif, baik secara nasional maupun internasional dalam perolehan pekerjaan, selain bekerja di bidang peternakan secara umum, lulusan bisa menjadi ahli atau dokter di bidang peternakan. Juga bisa menjadi orang yang bekerja di pemerintahan dan bahkan luar negeri untuk mengurusi bidang ternak. Kompetensi dosen dan Tendik di FAPET telah dibuktikan mampu bersaing baik ditingkat IPB maupun Nasional. Hal ini terbukti pada tahun 2014 di tingkat IPB, Dosen mendapatkan peringkat ke 2 dosen terbaik, PLP menduduki posisi ke 2, Keuangan ke 1, Akademik ke 2, Administrasi umum ke 3. Tahun 2015, dosen peringkat ke 3, PLP peringkat pertama IPB dan ke 2 tingkat Nasional, akademik peringkat ke 1 IPB, keuangan ke 2. Tahun 2016, Dosen terbaik IPB diraih FAPET serta PLP peringkat ke 2, Adminitrasi Umum tingkat Pertama dan, keuangan peringkat ke 3 dan Akademik peringkat 1. Hal lainnya mahasiswa FAPET mampu meraih beberapa predikat dan penghargaan baik dibidang akademik maupun PKM. Lulusan FAPET siap untuk bekerja diberbagai bidang ilmu, di lembaga pemerintah maupun swasta dan banyak yang menduduki jabatan penting sebagai pengambil kebijakan dan keputusan.

Berdasarkan pendataan pada tahun 2016 dan dipetakan dengan kompetensinya, ternyata ditemukan masalah dalam penempatan tendik, maka FAPET harus meningkatkan mutu pendidikan yang diberikannya kepada stakeholders utamanya, yaitu mahasiswa. Peningkatan tersebut hanya bisa dicapai melalui pergeseran paradigma dalam penyelenggaraan pendidikan tinggi. Sebuah organisasi agar dapat bertahan hidup di lingkungan bisnis kompetitif harus terus menerus melakukan perubahan dalam proses bisnisnya, sesuai perkembangan kondisi pasar (Aradea et al. 2010). Selain itu, adanya kemudahan yang diperoleh dalam era globalisasi saat ini, muncul kompetisi sangat ketat yang berakibat pelanggan semakin banyak pilihan dan semakin sulit dipuaskan, karena telah terjadi pergeseran yang semula hanya untuk memenuhi kebutuhan, meningkat menjadi harapan (expectation) untuk memenuhi kepuasan. Kepuasan pelanggan menjadi petunjuk arah dan pendorong motivasi untuk menciptakan langkah kreatif, inovatif yang dapat membentuk keadaan masa depan yang gemilang (Yamit, 2013). Hal ini menarik untuk diteliti dan dianalisis untuk menunjang rencana perubahan yang akan dilakukan FAPET menuju Unit Pendidikan Unggulan.

Perumusan masalah yang diteliti dalam penelitian ini berkaitan dengan motivasi, kompensasi, budaya organisasi dan kompetensi terhadap kinerja tendik. Motivasi yang tinggi akan memengaruhi capaian kinerja sesuai tujuan dari suatu instansi (Larasati dan Gilang, 2014). Motivasi juga berpengaruh terhadap kepuasan kerja (Koesmono, 2005). Motivasi juga berpengaruh terhadap karir dan reward (Firmansyah, 2016). Menurut Nurcahyani dan Adnyani (2016) menyatakan bahwa kompensasi, motivasi, dan kepuasan kerja berpengaruh nyata terhadap kinerja. Remunerasi berpengaruh nyata terhadap terhadap kinerja (Ikhya, 2016). Kompensasi finansial dan non finansial berpengaruh nyata terhadap kinerja (Apriyani, 2013). Marisa (2014) berpendapat bahwa budaya organisasi dan manajemen konflik berpengaruh nyata terhadap kinerja. Begitu juga dengan Suharyanto (2011) berpendapat bahwa gaya kepemimpinan dan budaya organisasi berpengaruh nyata terhadap kinerja. 
Perubahan lingkungan internal dan eksternal yang dialami oleh perguruan tinggi di Indonesia menunjukkan pergeseran, dari berorientasi sebagai penyedia jasa pendidikan menjadi berorientasi pada mahasiswa. Pemenuhan kebutuhan dan harapan mahasiswa menjadi harapan baru bagi FAPET untuk menuju unit pendidikan unggulan di masa depan agar menjadi gemilang melalui upaya perbaikan dan perubahan yang akan dilakukan, agar dapat optimal, Tendik merupakan penunjang dari aktivitas kegiatan pendidikan, penelitian dan pengabdian kepada masyarakat (PKM) dari suatu lembaga pendidikan yang bertujuan menjadi lembaga pendidikan berkelas internasional (Word Class University) maka perlu dilakukan perencanaan yang baik mengenai SDM.

Peran Tendik, baik PNS maupun non PNS sangat diperlukan dalam mencapai unit pendidikan unggulan di Fakultas Peternakan maka dari itu kompetensi tendik sangat perlu diperhatikan dengan memberikan motivasi dari para pimpinan dan lingkungan kerja serta memberikan kompensasi yang seimbang dengan hasil kerjanya unruk menciptakan kinerja yang optimal. Dengan demikian, tujuan penelitian ini adalah 1) menganalisi pengaruh Motivasi terhadap kompensasi; 2) menganalisis pengaruh kompensasi terhadap budaya organisasi dengan motivasi sebagai intervening; 3) menganalisis pengaruh kompensasi terhadap kompetensi dengan budaya organisasi sebagai intervening; dan 4) Penganalisis pengaruh motivasi terhadap kompetensi.

Ruang lingkup penelitian ini terfokus pada tenaga kependidikan di Fakultas Peternakan dengan melakukan pengukuran kinerja melalui motivasi, budaya organisasi ,kompensasi dan kompetensi melaului kuesioner. Hasil analisa tersebut, akan menjadi acuan dalam merumuskan prioritas strategi manajemen perubahan menuju Unit Pendidkan Unggulan Fapet di masa yang akan datang.

\section{METODE PENELITIAN}

Penelitian ini dilakukan di FAPET IPB Darmaga. Pengumpulan data dilakukan selama 4 bulan, FebruariMei 2017, selanjutnya dilakukan analisis terhadap data yang diperoleh. Data yang digunakan dalam penelitian ini adalah data primer dan skunder yang berkaitan dengan penelitian. Data primer diperoleh dari pengisian kuesioner oleh seluruh Tendik FAPET IPB, yaitu sebanyak 142 orang. Data skunder diperoleh melalui berbagai sumber studi pustaka, seperti jurnal, buku, dan laporan yang dikeluarkan oleh instansi/lembaga, serta dari literatur internet yang terkait dengan penelitian.

Pada penelitian ini populasinya adalah Tendik Fapet IPB baik PNS maupun non PNS. Jumlah populasinya yang tercatat pada data Tendik Fapet IPB tahun 2016 adalah sebesar 142 orang. Penelitian ini adalah deskriptif dengan menggunakan survei yang bertujuan memperoleh gambaran suatu keadaan tentang pengaruh motivasi, kompensasi, budaya organisasi dan kompetensi Tendik terhadap kinerja. Penelitian dengan tehnik survei didefinisikan sebagai penelitian yang dilakukan terhadap populasi dan sampel dari peubah yang diteliti melalui pengumpulan data secara kuantitatif menggunakan kuesioner. Kemudian data yang terkumpul akan diolah dan dianalisa melalui teknik statistik untuk menganalisa secara umum tentang pengaruh motivasi, kompensasi, budaya organisasi dan kompetensi terhadap pencapaian kinerja.

Model-model pengukuran motivasi kerja telah banyak dikembangkan, diantaranya oleh Mcclelland (dalam Mangkunegara, 2005) mengemukakan enam karakteristik orang yang mempunyai motivasi berprestasi tinggi, yaitu (1) memiliki tingkat tanggung jawab pribadi yang tinggi, (2) berani mengambil dan memikul risiko, (3) memiliki tujuan realistic, (4) memiliki rencana kerja yang menyeluruh dan berjuang untuk merealisasikan tujuan, (5) memanfaatkan umpan balikyangkonkritdalam semuakegiatanyangdilakukan, dan (6) mencari kesempatan untuk merealisasikan rencana yang telah yang telah diprogramkan. Edward Murray (dalam Mangkunegara, 2005) berpendapat bahwa karakteristik orang yang mempunyai motivasi berprestasi tinggi adalah sebagai berikut: (1) melakukan sesuatu dengan sebaik-baiknya, (2) melakukan sesuatu dengan mencapai kesuksesan, (3) menyelesaikan tugastugas yang memerlukan usaha dan keterampilan, (4) berkeinginan menjadi orang terkenal dan menguasai bidang tertentu, (5) melakukan hal yang sukar dengan hasil yang memuaskan, (6) mengerjakan sesuatu yang sangat berarti, dan (7) melakukan sesuatu yang lebih baik dari orang lain.

Penelitian ini menggunakan Structural Equation Modeling (SEM), karena SEM merupakan analisis yang tepat digunakan untuk analisis multivariat dalam penelitian sosial, selain itu penelitian juga harus menggunakan peubah laten (peubah yang tidak bisa 
diukur secara langsung), yaitu motivasi, kompensasi, budaya organisasi dan kompetensi sehingga penelitian harus menggunakan beberapa indikator atau pertanyaan kuesioner. Selain itu SEM mampu menguji penelitian yang kompleks dan banyak peubah secara simultan. SEM dapat menyelesaikan analisa dengan satu kali estimasi, SEM dapat melakukan analisis faktor, regresi dan jalur sekaligus. Kerangka pemikiran penelitian selengkapnya pada Gambar 1.

Model pemikiran dikembangkan untuk mengetahui faktor-faktor yang secara langsung dan tidak langsung memengaruhi kinerja pegawai, sehingga dapat dirumuskan upaya untuk meningkatkan kinerja Tendik di Fapet IPB. Faktor-faktor tersebut terdiri dari faktor motivasi, kompetensi, kompensasi dan budaya organisasi. Berdasarkan rumusan masalah, tujuan penelitian dan landasan teori disusun model pemikiran yang berfungsi sebagai penuntun alur pikir dan sekaligus sebagai dasar dalam penelitian ini seperti pada Gambar 2. Model pemikiran penelitian ini dikembangkan berdasarkan pada teori dan hasil penelitian terdahulu. Teori yang digunakan diantaranya diungkapkan oleh
Arep dan Tanjung (2003) menyatakan manfaat motivasi yang utama adalah menciptakan gairah kerja sehingga produktivitas meningkat. Hasil penelitian Diyanti et al. (2016) menyatakan bahwa motivasi kerja dan iklim kerja berpengruh nyata terhadap kinerja tendik IPB.

Untuk mengetahui pengaruh motivasi, kompensasi, budaya organisasi dan kompetensi terhadapkinerja kinerja maka hipotesisnya dirumuskan sebagai berikut:

Hipotesis 1

H0 : Kompensasi tidak berpengaruh terhadap motivasi

H1 : Kompensasi berpengaruh terhadap motivasi.

\section{Hipotesis 2}

H0 : Kompensasi tidak berpengaruh terhadap budaya organisasi, dimana motivasi sebagai peubah intervening.

H1 : Kompensasi berpengaruh terhadap budaya organisasi, dimana motivasi sebagai peubah intervening.

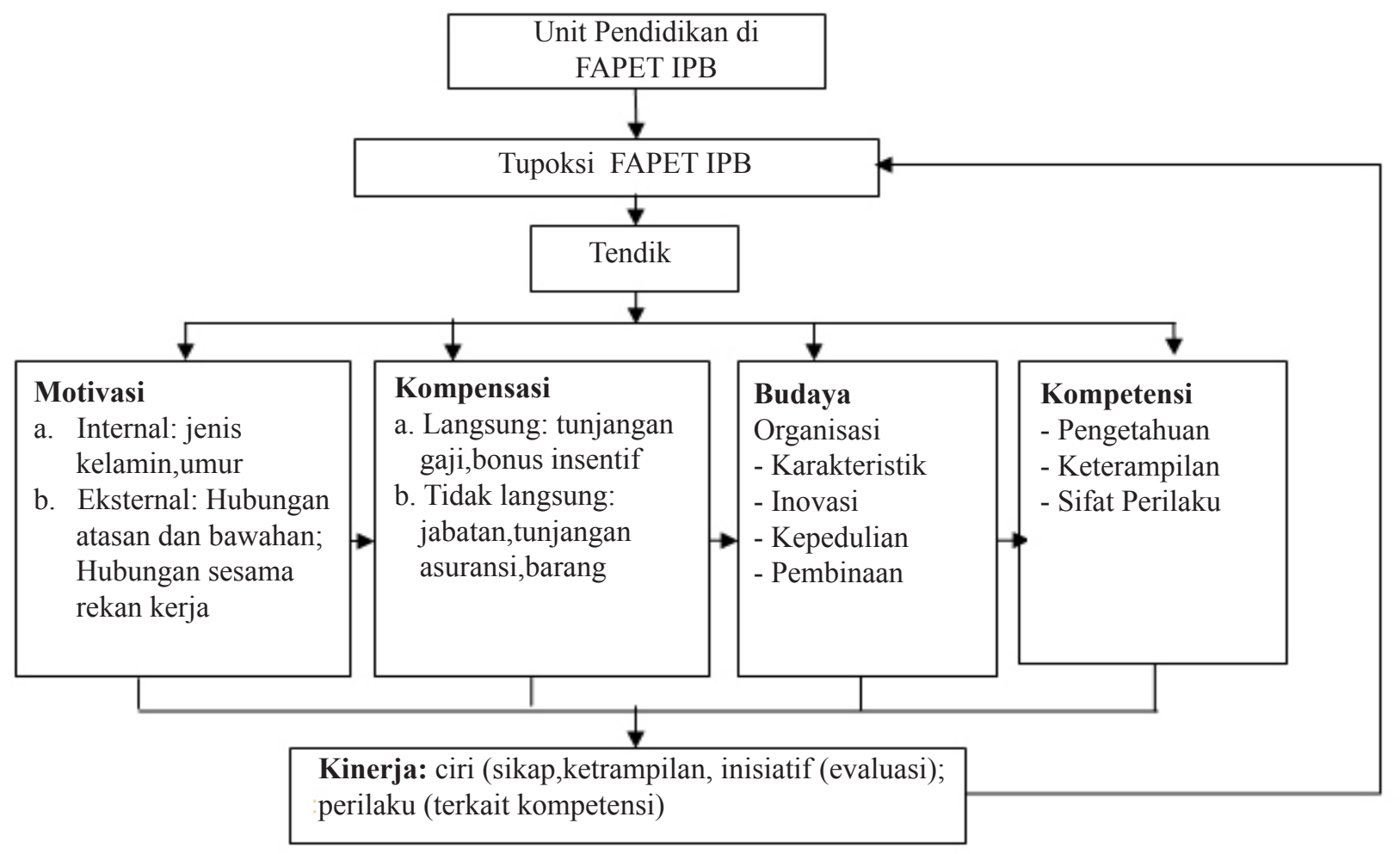

Gambar 1. Kerangka pemikiran penelitian 


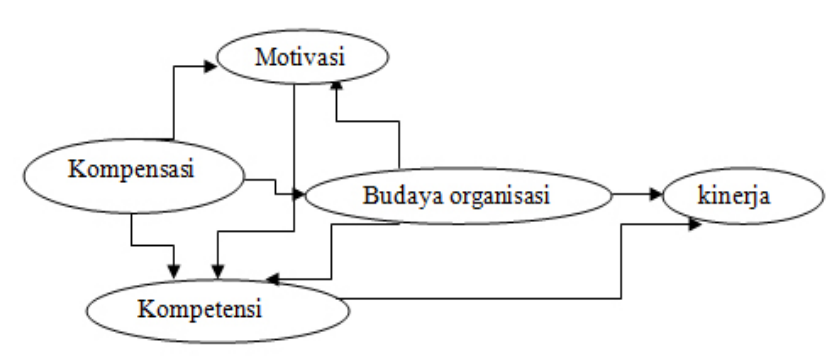

Gambar 2. Model pemikiran penelitian

Hipotesis 3

H0 : Kompensasi tidak berpengaruh terhadap budaya organisasi, dimana budaya organisasi sebagai peubah intervening.

H1 : Kompensasi berpengaruh terhadap budaya organisasi, dimana budaya organisasi sebagai peubah intervening.

Hipotesis 4

HO : Budaya Organisasi tidak berpengaruh nyata terhadap kompetensi.

H1 : Budaya Organisasi berpengaruh nyata terhadap kompetensi.

\section{HASIL}

\section{Karakteristik responden}

Proses awal penelitian ini adalah melakukan analisis terhadap karakteristik responden berdasarkan jenis kelamin, usia, status pernikahan dan pendidikan terakhir.
Dalam penelitian ini ada 142 responden Tendik FAPET IPB, baik PNS maupun non PNS. Tehnik pengumpulan datanya adalah dengan indepth interview kepada responden untuk menjawab setiap pertanyaan demi untuk mendapatkan gambaran sesungguhnya terhadap persepsi responden. Jumlah responden terbagi dalam tiga kelompok usia, yaitu $<34$ tahun, 34-46 tahun dan $>46$ tahun. Responden sebagian besar adalah pria $(71,1 \%)$ dengan pendidikan terakhir sebagian SLTA dan Sarjana (47,9\%). Responden adalah Tendik FAPET IPB dengan usia yang bervariasi, dengan masa kerja rata-rata di atas 24 tahun (40,5\%).

Hasil SEM evaluasi model pengukuran diawali dengan melihat nilai loading factor pada setiap konstruk latin. Apabila terdapat indikator yang memiliki nilai loading factor $<0,5$ harus dilakukan calculating kembali terhadap model awal sehingga seluruh indikator reflektif menghasilkan loading factor $>0,5$ sebagai kriteria dari uji validitas convergent konstruk laten (Ghozali, 2008). Gambar 3 menunjukkan terdapat indikator yang memiliki nilai loading factor $<0,5$ sehingga perlu dilakukan iterasi kembali terhadap model. Setelah dilakukan beberapa iterasi, diperoleh model akhir ditunjukkan pada Gambar 4, yang menunjukan semua indikator telah memiliki nilai loading factor $>0,5$.

Dari hasil SEM dinyatakan bahwa indikator yang dapat memotivasi kinerja Tendik Fapet IPB dipengaruhi oleh faktor kompensasi. Hasil penelitian menunjukaan bahwa:

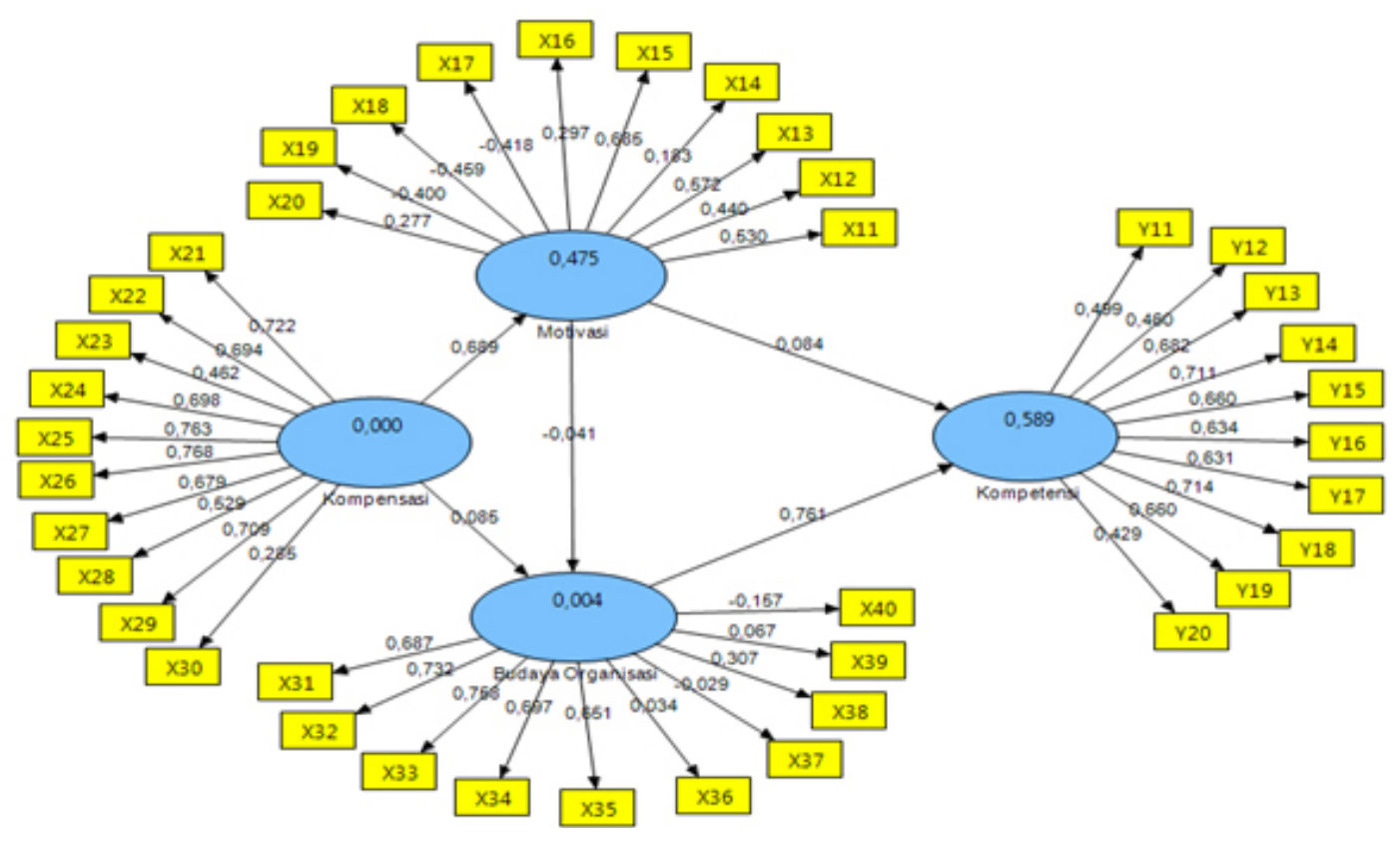

Gambar 3. Loading factor pada model pengukuran awal 


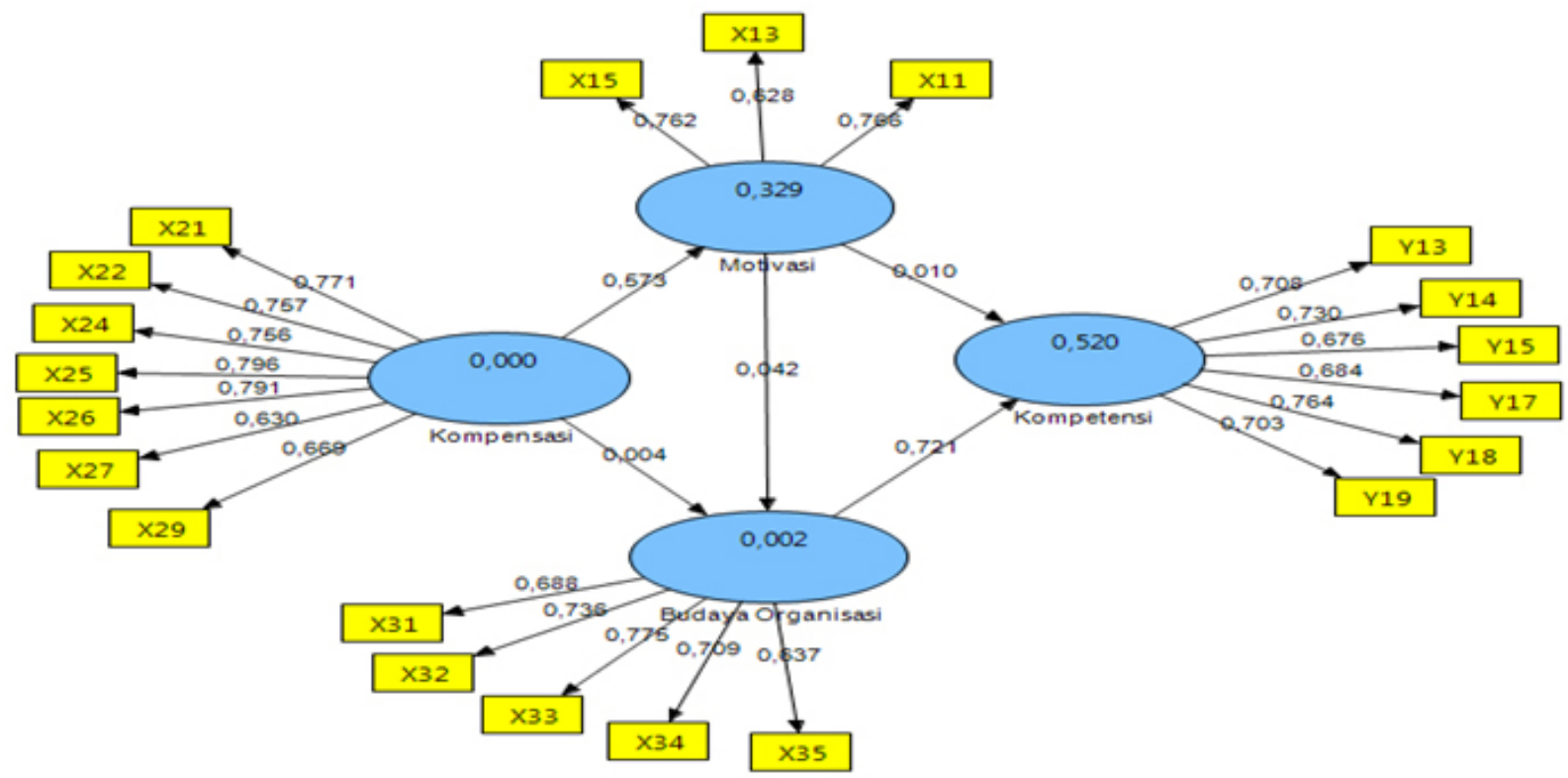

Gambar 4. Gambar model SEM PLS

Pengaruh kompensasi terhadap motivasi, berpengaruh nyata terhadap Motivasi Tendik FAPET IPB dengan nilai T-statistik 14,78 lebih besar dari T-tabel yaitu 1,96, dengan demikian hipotesis 1 dapat diterima. Penelitian ini menunjukkan faktor yang paling dominan dalam pencapaian kinerja yang optimal adalah peubah kompetensi dengan nilai 0,520 dan motivasi 0,329. Syarat model memiliki validitas yang baik, yaitu masing-masing peubah dengan indikator reflektif memiliki AVE di atas 0,5. Hasil analisis yang terlihat pada Tabel 1, dimana nilai AVE dari masing-masing peubah memiliki nilai $>0,5$ maka dapat dikatakan bahwa model PLS memenuhi syarat validitas convergent yang baik.

Kompensasi membantu organisasi mencapai tujuannya dan memperoleh serta mempertahankan karyawan yang produktif (Suharto dan Yamit, 2005). Jika kompensasi yang diterima semakin tinggi maka akan semakin meningkatkan kepuasan kerja karyawan dalam sebuah perusahaan. Dengan menganalisis motivasi maka akan menghasilkan kinerja yang optimal. Hasil penelitian ini juga didukung oleh Murty dan Hudiwinarsih (2012), yang menyatakan bahwa kurangnya motivasi kerja dari pimpinan untuk karyawan akan menghambat kinerja dan juga membuat suasana kerja tidak kondusif. Selain itu juga didukung oleh Garry Dessler (dalam Kunartinah, 2012) mendefinisikan kompensasi adalah semua bentuk penggajian atau ganjaran yang mengalir kepada pegawai dan timbul dari kepegawaiannya. Kompensasi menunjukkan pada semua hal baik berwujud pada balas jasa berupa finansial maupun non finansial dari perusahaan kepada karyawannya. Jika kompensasi yang diterima karyawan adalah tinggi, maka karyawan akan merasa semakin puas. Sebaliknya jika kompensasi yang diterima oleh karyawan sedikit maka karyawan akan merasa tidak puas dalam bekerja. Dengan demikian hipotesis 2 dapat diterima.

Pengaruh kompensasi terhadap Budaya Organisasi dimana motivasi sebagai intervening. Kompensasi tidak berpengaruh nyata terhadap budaya organisasi melalui peubah intervening motivasi dengan nilai t-statistik $(0,380)<\mathrm{t}$-tabel $(1,960)$. Dengan demikian hipotesis 3 tidak diterima.

Pengaruh Kompensasi terhadap kompetensi melalui variabel intervening budaya organisasi. Pengaruh Kompensasi terhadap kompetensi melalui variabel intervening budaya organisasi menunjukkan bahwa kompensasi tidak berpengaruh nyata terhadap kompetensi dimana budaya organisasi sebagai intervening, dengan nilai t-statistik $(0,424)<\mathrm{t}$-tabel $(1,960)$. Model struktural kompetensi menghasilkan nilai R-square 52\%. Artinya, keragaman kompetensi yang mampu dijelaskan oleh model sebesar 52\% sedangkan sisanya $48 \%$ dijelaskan oleh faktor lain diluar model. 
Tabel 1. Nilai average variance extraxted (AVE), dan composite reliability

\begin{tabular}{lcc}
\hline & AVE & Composite Reliability \\
\hline Budaya organisasi & 0,505 & 0,836 \\
Kompensasi & 0,549 & 0,894 \\
Kompetensi & 0,506 & 0,860 \\
Motivasi & 0,521 & 0,764 \\
\hline
\end{tabular}

Pengaruh budaya organisasi terhadap kompetensi memiliki pengaruh langsung nyata terhadap kompetensi dengan nilai t-statistik $(22,39)>\mathrm{t}$-tabel $(1,96)$ pada taraf nyata $5 \%$. Dengan demikian hipotesis 4 dapat diterima. Kompensasi berpengaruh nyata terhadap motivasi dengan nilai t-statistik $(14,78)>$ t-tabel $(1,96)$ pada taraf nyata $5 \%$. Semakin baik budaya organisasi yang tercipta pada setiap divisi maka akan semakin meningkatkan kompetensi. Begitu dengan dukungan kompensasi tinggi, yaitu semakin meningkatkan motivasi. Disisi lain kompensasi tidak berpengaruh nyata terhadap kompetensi melalui peubah intervening budaya organisasi dengan nilai t-statistik $(0,424)<$ t-tabel $(1,960)$ (Tabel 2). Model struktural kompetensi menghasilkan nilai R-square 52\%. Artinya, keragaman kompetensi mampu dijelaskan oleh model $52 \%$ dan sisannya (48\%) dijelaskan oleh faktor lain diluar model.

\section{Implikasi manajerial}

Tendik merupakan faktor penting dalam keberhasilan menciptakan unit pendidikan unggulan di suatu Perguruan Tinggi. Maju dan mundurnya Perguruan Tinggi tergantung pada kualitas SDM, salah satu yang dapat dilakukan perguruan tinggi dalam meningkatkan motivasi serta meningkatkan kinerja adalah dengan memberikan kompensasi yang seimbang baik kompensasi secara langsung maupun tidak langsung, juga menjaga budaya organisasi dengan saling mengucapkan terimakasih serta memberikan bonus berkala berupa rekreasi keluarga serta memberikan kesempatan untuk belajar bagi tendik agar kompetensinya semakin baik.

Penelitian menunjukan bukti nyata bahwa kompensasi yang baik akan meningkatkan motivasi serta meningkatkan kompetensi tendik sehingga akan meningkatkan kinerjanya. Berdasarkan hal tersebut maka penting bagi pimpinan untuk memperhatikan serta meningkatkan kompensasi agar meningkatkan motivasi kerja tendik.

\section{KESIMPULAN DAN SARAN}

\section{Kesimpulan}

Kompetensi menunjukkan memiliki pengaruh nyata terhadap budaya organisasi dengan nilai t-statistik $(22,39)>$ T-tabel $(1,96)$ pada taraf nyata $5 \%$. Kompensasi berpengaruh nyata terhadap motivasi dengan nilai t-statistik $(14,78)>$ t-tabel $(1,96)$ pada taraf nyata $5 \%$. Semakin baik budaya organisasi yang tercipta pada setiap divisi maka akan semakin meningkatkan kompetensi. Begitu juga dengan dukungan kompensasi yang tinggi maka semakin meningkatkan motivasi. Kompensasi tidak berpengaruh nyata terhadap budaya organisasi melalui variabel intervening motivasi dengan nilai t-statistik $(0,380)<\mathrm{t}$-tabel $(1,960)$. Kompensasi tidak berpengaruh nyata terhadap kompetensi melalui variabel intervening budaya organisasi dengan nilai t-statistik $(0,424)<$ t-tabel $(1,960)$. Model struktural kompetensi menghasilkan nilai R-square 3\%. Artinya, keragaman kompetensi yang mampu dijelaskan oleh model sebesar 3\%, sedangkan sisanya 97\% dijelaskan oleh faktor lain diluar model.

Tabel 2. Nilai loading factor dan t-statistik pengaruh total

\begin{tabular}{|c|c|c|c|}
\hline & Loading factor & T-statistik & R square \\
\hline Kompensasi $\rightarrow$ Motivasi & 0,573 & 14,780 & 0,520 \\
\hline Kompensasi $\rightarrow$ Motivasi $\rightarrow$ Budaya Organisasi & 0,028 & 0,380 & \\
\hline Kompensasi $\rightarrow$ Budaya Organisasi $\rightarrow$ Kompetensi & 0,026 & 0,424 & \\
\hline Motivasi $\rightarrow$ Kompetensi & 0,010 & 0,276 & \\
\hline Budaya Organisasi $\rightarrow$ Kompetensi & 0,721 & 22,398 & \\
\hline
\end{tabular}

Keterangan: T-statistik $>1,96$ yang berarti berpengaruh signifikan pada taraf 5\% 


\section{Saran}

Dilakukan penelitian lanjutan tentang peran Tendik yang masih belum tercapai (97\%, diluar model) meliputi Semua akademisi di Fapet IPB Tidak hanya sebatas tendik, agar menghasilkan kinerja optimal sehingga bisa mengukur seberapa besar peran Tendik dalam mencapai unit pendidikan unggulan di Fapet IPB. Untuk meningkatkan kinerja tendik Fapet IPB, maka perlu diperhatikan hal yang terkait dengan kompensasi secara langsung maupun tidak langsung melalui pemberian insentif, uang lembur, hadiah dan bonus tahuan. Meningkatkan budaya organisasi secara terencana terarah dan teratur melalui kegiatan seperti coffee morning, outboud, piknik dll.

\section{DAFTAR PUSTAKA}

Arep I, Tanjung H. 2003. Manajemen Motivasi. Jakarta: PT. Gramedia.

Aradea, Yuliana A, Himawan H. 2010. Penerangan change management untuk peningkatan proses bisnis dalam meraih keunggulan kompetitif organisasi. Di Dalam: Seminar Nasional Informatika UPN "Veteran"; 2010 Mei 22; Yogyakarta, Indonesia. hlm. 27-36.

Diyanti D, Hubeis M, Affandi M. 2017. Pengaruh motivasi kerja dan iklim kerja terhadap kepuasan kerja dan implikasinya terhadap kinerja tenaga kependidikan Institut Pertanian Bogor. Jurnal Aplikasi Bisnis dan Manajemen 3(3): 361-372. http://dx.doi.org/10.17358/jabm.3.3.361.

Firmansyah Y. 2016. Analisis karakteristik individu, karakteristik pekerjaan dan employe engagement terhadap kinerja tenaga kependidikan Universitas Andalas [tesis]. Bogor: Institut Pertanian Bogor.
Ghozali I. 2008. Structural Equation Modelling (SEM) Metode Alternatifdengan Partial Least Square (PLS). Edisi 4. Semarang: Badan penerbit Universitas Diponegoro.

Ihkya A. 2016. Pengaruh remunerasi motivasi dan disiplin terhadap kinerja [tesis]. Jakarta: Universitas terbuka.

Koesmono T. 2005. Pengaruh budaya organisasi terhadap motivasi dan kepuasan kerja serta kinerja karyawan pada sub sektor industri pengolahan kayu skala menengah Di Jawa Timur. Jurnal Manajemen \& Kewirausahaan, 7(2): 171-188.

Larasati S, Gilang A.2014. Pengaruh motivasi kerja terhadap kinerja karyawan wilayah Telkom Jabar Barat Utara (Witel Bekasi). Jurnal Manajemen dan Organisasi 5(3): 200-213. https://doi. org/10.29244/jmo.v5i3.12167.

Mangkunegara AP. 2005. Evaluasi Kerja. Bandung: Penerbit Refika Aditama.

Maria AS. 2014. Pengaruh budaya organisasi dan manajemen konflik terhadap kepuasan kerja perugas rawat inap rumah sakit umum daerah Kota Padang Sidampuan [tesis]. Medan: Universitas Sumatra Utara.

Nurcahyani, Adnyani D. 2016. Pengaruh konpensasi dan motivasi terhadap kinerja karyawan dengan kepuasan kerja sebagai variabel intervening Fakultas Ekonomi dan Bisnis Universitas Udayana. E-Jurnal Manajemen Unud 5(1): 500532.

Suharyanto. 2011. Pengaruh gaya kepemimpinan dan budaya organisasi terhadap kinerja pegawai di Universitas PGRI Adibuana Surabaya [tesis]. Surabaya: Universitas Narotama.

Yamit Z. 2013. Manajemen Kualitas Produk dan Jasa. Yogyakarta: Ekonisia. 